\title{
Standardization of Brahmi Ghrita with Special reference to Its Pharmaceutical Study
}

\author{
Research article
}

\section{Yadav Kapil Deo ${ }^{1}$, Reddy $\mathrm{KRC}^{2 *}$}

1. Junior Resident 2. Associate Professor

Department of Rasa Shastra, Faculty of Ayurveda IMS, BHU, Varanasi. Email: drkrcreddybhu@yahoo.co.in

\begin{abstract}
Brahmi Ghrita is a preparation of Brahmi (Bacopa monneri), Vacha (Acorus calamus), Kushtha (Sassurea lappa), Shankhapushpi (Convolvulos pluricalis) and Purana Ghrita. This preparation is used for the treatment of Apasmara and prepared by Sneha Paka process as mentioned in classical text books of Ayurveda. Three samples of this Ghrita were prepared and each sample of Brahmi Ghrita, containes Brahmi in Swarasa form as a drava dravya. Kalka was prepared with fine powder of Vacha, Kushtha, Shankhapushpi and Brahmi by triturating with Brahmi Swarasa. Murchhana of Ghrita was done as per procedure before using the Ghrita as Sneha dravya. By using all drugs, Brahmi Ghrita was prepared on mild heat for three day and during the manufacturing process temperature as well as Siddhi lakashana mentioned in Ayurveda was recorded.
\end{abstract}

Key words: Brahmi Ghrita, Sneha Paka, Murchhana

\section{Introduction}

Ayurveda is a science of living being. It describes various diseases including Sharirik vyadhi (Somatic disorders), Manshik vyadhi (Psychological disorders) and Manshik- Sharirikvyadhi (Psycho-Somatic disorders). Both types of disorders are also interchangeable and affect each other. In Ayurveda, Manshika vyadhi is described in the form of Unmada and Apasmara. Unmada is the disorder which occurs due to Budhhi Vibhram [1] and Apasmara is a type of disorder which occurs due to Smriti parivarsan [2].Various single as well as compound formulations were described for the treatment of Apasmara. Brahmi Ghrita is

*Corresponding Author:

Dr. KRC Reddy

Associate Professor

IMS, BHU

Varanasi, India

E-mail: drkrcreddybhu@yahoo.co.in an important formulation for the treatment of Apasmara. Different classical text books of Ayurveda mentioned different compositions of Brahmi Ghrita. Hence in present thesis work a step is made to evaluate best formula of Brahmi Ghrita, which can be prepared in large scale manufacturing. For present Pharmaceutical Study of Brahmi Ghrita we followed reference of Charaka Samhita. Brahmi ghrita is prepared with Brahmi, Vacha, Kushtha, Shankhapushpi and Purana Ghrita [3] (Old ghee) which is indicated for the treatment of Apasmara and Graha disorders.

\section{Materials and Methods}

Fresh Brahmi plants were collected from Ramanagar,Varanasi Distt (U.P). Vacha, Kushtha, Shankhapushpi collected from local market of Varanasi and GoGhrita was procured from Jalan shop (A Local Market of Varanasi). All procedures were done in the Department of Rasa 
Shastra, except preparation of Brahmi swarasa which was prepared in Ayurvedic Pharmacy, Institute of Medical Sciences, Banaras Hindu University, Varanasi. Then Brahmi Ghrita was prepared by Sneha paka process.

\section{Murchhana of Ghrita}

The purpose of Murchhna is remove its Daurgandh, Ama Dosh from the crude form of go Ghrita. Murchhana of Ghrita was done with Amalaki (Emblica officinalis), Vibhitaki (Terminalia bellirica), Haritaki (Terminalia chebula), Haridra (Curcuma longa), Musta (Cyperus rotundus) and Matulunga Swarasa [4](Detailes about quantity of each ingredient is mentioned in table1). Amalaki, Vibhitaki, Haritaki, Haridra, Musta are dried in sunlight till the material become moisture less form then this material was made in to fine powder form. After that, fine powder of above mentioned drugs were put in to kharal (Mortar) and appropriate quantity of Matulunga swarasa (Fresh juice) of Matulung was added. In order to start the process, the Ghrita is taken in to container and heated with mild temperature, then kalka and water were incorporated. Then the total mixture of material was processed over mild heat. During the heating process material is stirred continuously in order to avoid sticking of kalka to bottom of container and also avoid burning of kalka. Each day three hours heating process was done like this process was completed in three days. This murchhita ghrita was used in preparation of Brahmi Ghrita.

\section{Preparation of Brahmi Swarasa}

Brahmi Swarasa was prepared in Ayurvedic Pharmacy, IMS, Banaras Hindu University, Varanasi. First of all whole parts of fresh Brahmi plant were collected and washed with fresh water to remove clay and larger foreign material intact with plant material. Then with the help of sharp cutting instrument Brahmi plant material were cut in to small pieces. After cutting in to small pieces of Brahmi plant material, these small pieces of Brahmi were put in to End runner, plant material were crushed and made into kalka (paste). This Kalka was taken into new cotton cloth and compressed, to obtain the Brahmi Swarasa (juice).

\section{Preparation of Kalka Dravya}

Brahmi, Vacha, Kushtha and Shankhapushpi were dried in sunlight. When all plant material was dried, then fine powder of Brahmi, Vacha, Kushtha and Shankhapushpi is prepared separately with the help of mortar and pestle. After that, all ingredients were mixed with each other in khalva yantra and triturated with Brahmi Swarasa. In this way Kalka (Paste) was prepared.

\section{Preparation of Brahmi Ghrita}

Brahmi Ghrita was prepared with Murchhita Ghrita. First of all Murchhita Ghrita was heated on mild heat, when Ghrita was slightly warm then Brahmi Swarasa was added into it and mixed thoroughly, during mixing of Swarasa heating process was continued. Then Kalka dravya was added. After adding the kalka dravya continuous stirring of whole material was done.

In first day whole material was heated up to boiling for one hour, after that heating process was stopped on first day. In second day heating process was started again and heated for five hours after that, heating process was again stopped. In third day heating process again started and continued up to obtaining

Sneha siddhi lakashana like varti-vat Sneha kalka (wick-like shape), sabdhinoagni nikshipto (does not produce crackling sound on fire) etc. When Sneha siddhi lakashana ${ }^{5}$ was obtained, then Ghrita was filtered with the help of cotton cloth. This filtered Ghrita was known as Brahmi Ghrita. Thus Brahmi Ghrita was prepared in three days of discontinuous heating ${ }^{6}$. In 
this way three samples of Brahmi Ghrita was prepared. (Details about quantity and temperature during pharmaceutical process mentioned in to table 3 and 4).

\section{Observations}

Initially $2.400 \mathrm{~kg}$ of Go- Ghrita (Cows Ghee) was taken for Murchhana process. After Murchhana process 2.250 $\mathrm{kg}$ of murchhita Ghrita was obtained. This $2.250 \mathrm{~kg}$ of Murchhita Ghrita was used for preparation of Brahmi Ghrita. Brahmi Ghrita, was prepared in to three batches, so that $2.250 \mathrm{~kg}$ of Murchhita Ghrita was divided in to three equal parts. $0.750 \mathrm{~kg}$ of murchhita Ghrita was used for each batch of Brahmi Ghrita and $0.420 \mathrm{Kg}, 0.520 \mathrm{Kg}$ and $0.44 \mathrm{~kg}$ of Brahmi Ghrita was obtained respectively. Total duration of heating process required for preparation of Brahmi ghrita was 9.5, 10, 9.5 hours respectively. Total quantity of raw materials used in Brahmi Ghrita was 3 liters of Brahmi swarasa, $0.750 \mathrm{~kg}$ of Murchhita Ghrita and $120 \mathrm{mg}$ of kalka dravya of Brahmi, Vacha, Kushtha and Shankhapushpi. Total quantity $1.385 \mathrm{~kg}$ of Brahmi Ghrita was obtained in all three batches (details are mentioned in table 3 ).

Table 1: Showing drugs used in Murchhana of Ghrita

\begin{tabular}{|c|c|c|c|c|c|c|c|c|}
\hline & $\begin{array}{l}\text { Ghrit } \\
a\end{array}$ & Amla & $\begin{array}{l}\text { Vibhita } \\
\text { ki }\end{array}$ & $\begin{array}{l}\text { Harita } \\
\text { ki }\end{array}$ & $\begin{array}{l}\text { Nagkes } \\
\text { ar }\end{array}$ & $\begin{array}{l}\text { Haridr } \\
a\end{array}$ & $\begin{array}{l}\text { Matulung } \\
\text { Swarasa }\end{array}$ & $\begin{array}{l}\text { Wate } \\
r\end{array}$ \\
\hline Quantity & $\begin{array}{l}2.400 \\
\mathrm{~kg}\end{array}$ & $\begin{array}{l}100 \\
\mathrm{gm}\end{array}$ & $100 \mathrm{gm}$ & $100 \mathrm{gm}$ & $100 \mathrm{gm}$ & $\begin{array}{l}100 \\
\mathrm{gm}\end{array}$ & $100 \mathrm{gm}$ & ----- \\
\hline $\begin{array}{l}\text { Quantity after } \\
\text { drying/Squeezi } \\
\text { ng }\end{array}$ & ----- & $\begin{array}{l}90 \text { gm } \\
\text { (dryin } \\
\text { g) }\end{array}$ & $\begin{array}{lr}83 & \text { gm } \\
\text { (drying) }\end{array}$ & $\begin{array}{l}78 \mathrm{gm} \\
\text { (drying } \\
\text { ) }\end{array}$ & $\begin{array}{l}87 \text { gm } \\
\text { (drying) }\end{array}$ & $\begin{array}{l}84 \text { gm } \\
\text { (dryin } \\
\text { g) }\end{array}$ & $\begin{array}{l}60 \quad \mathrm{ml} \\
\text { Swarasa } \\
\text { (Squeezin } \\
\mathrm{g})\end{array}$ & ---- \\
\hline $\begin{array}{l}\text { Quantity of } \\
\text { powder }\end{array}$ & $\begin{array}{l}------ \\
\end{array}$ & $85 \mathrm{gm}$ & $80 \mathrm{gm}$ & $70 \mathrm{gm}$ & $80 \mathrm{gm}$ & $78 \mathrm{gm}$ & ----- & ----- \\
\hline Quantity used & $\begin{array}{l}2.400 \\
\mathrm{~kg}\end{array}$ & $38 \mathrm{gm}$ & $38 \mathrm{gm}$ & $38 \mathrm{gm}$ & $38 \mathrm{gm}$ & $38 \mathrm{gm}$ & $38 \mathrm{gm}$ & $\begin{array}{l}9.12 \\
\text { liter }\end{array}$ \\
\hline
\end{tabular}

Table 2: Showing drugs used in Preparation of Brahmi Ghrita

\begin{tabular}{|l|l|l|l|l|l|}
\hline & Ghrita & Brahmi & Vacha & Kushtha & Shankhapushpi \\
\hline Quantity & $\begin{array}{l}2.250 \\
\mathrm{~kg}\end{array}$ & $25 \mathrm{~kg}$ & $100 \mathrm{gm}$ & $100 \mathrm{gm}$ & $100 \mathrm{gm}$ \\
\hline $\begin{array}{l}\text { Quantity after Squeezing and } \\
\text { drying }\end{array}$ & -------- & $\begin{array}{l}\text { Swarasa 9 } \\
\text { liter }\end{array}$ & $89 \mathrm{gm}$ & $91 \mathrm{gm}$ & $86 \mathrm{gm}$ \\
\hline Quantity of powder & -------- & ------- & $84 \mathrm{gm}$ & $82 \mathrm{gm}$ & $78 \mathrm{gm}$ \\
\hline Quantity used/Sample & $\begin{array}{l}0.750 \\
\mathrm{~kg}\end{array}$ & $\begin{array}{l}\text { 3liter } \\
\text { Swarasa, } \\
48 \text { gm } \\
\text { Kalka) }\end{array}$ & $24 \mathrm{gm}$ & $24 \mathrm{gm}$ & $24 \mathrm{gm}$ \\
\hline
\end{tabular}

Table 3: Showing details about pharmaceutical process of Brahmi Ghrita

\begin{tabular}{|l|l|l|l|}
\hline Parameter & Sample A & Sample B & Sample C \\
\hline $\begin{array}{l}\text { Total weight of } \\
\text { Raw Material }\end{array}$ & $\begin{array}{l}\text { 3 liter }(\text { Swarasa })+ \\
\begin{array}{l}0.870 \text { gm }(\text { Ghrita } \\
+ \text { Kalka })\end{array}\end{array}$ & $\begin{array}{l}\text { 3 liter }(\text { Swarasa })+ \\
\begin{array}{l}\text { (S7) gm }(\text { Ghrita } \\
+ \text { Kalka })\end{array}\end{array}$ & $\begin{array}{l}\text { 3 liter }(\text { Swarasa })+ \\
\begin{array}{l}0.870 \text { gm }(\text { Ghrita } \\
+ \text { Kalka })\end{array}\end{array}$ \\
\hline
\end{tabular}




\begin{tabular}{|l|l|l|l|}
\hline $\begin{array}{l}\text { Temperature } \\
\text { Outside the } \\
\text { container }\end{array}$ & $225^{0} \mathrm{C}$ & $230{ }^{\circ} \mathrm{C}$ & $245{ }^{0} \mathrm{C}$ \\
$\begin{array}{l}\text { Temperature } \\
\text { inside } \\
\text { container }\end{array}$ & $105^{0} \mathrm{C}$ & $107^{0} \mathrm{C}$ & $103^{0} \mathrm{C}$ \\
\hline $\begin{array}{l}\text { Temperature of } \\
\text { Kalka on } 3^{\text {rd }} \text { day }\end{array}$ & $93{ }^{0} \mathrm{C}$ & $94^{0} \mathrm{C}$ & $93{ }^{0} \mathrm{C}$ \\
\hline $\begin{array}{l}\text { Weight of Brahmi } \\
\text { Ghrita }\end{array}$ & $420 \mathrm{gm}$ & $520 \mathrm{gm}$ & $445 \mathrm{gm}$ \\
\hline $\begin{array}{l}\text { Weight of Kalka } \\
\text { dravya }\end{array}$ & $600 \mathrm{gm}$ & $510 \mathrm{gm}$ & $580 \mathrm{gm}$ \\
\hline $\begin{array}{l}\text { Total duration of } \\
\text { Agni }\end{array}$ & $9.5 \mathrm{hrs}$ & $10 \mathrm{hrs}$ & $9.5 \mathrm{hrs}$ \\
\hline
\end{tabular}

Table 4: Showing Break up of temperature given for three samples in three days

\begin{tabular}{|l|l|l|l|}
\hline Days & Sample A & Sample B & Sample C \\
\hline $1^{\text {st }}$ day & $1.2 \mathrm{hrs}$ & $1.2 \mathrm{hrs}$ & $1.2 \mathrm{hrs}$ \\
\hline $2^{\text {nd }}$ day & $3.6 \mathrm{hrs}$ & $3.6 \mathrm{hrs}$ & $3.6 \mathrm{hrs}$ \\
\hline $3^{\text {rd }}$ day & $4.7 \mathrm{hrs}$ & $4.7 \mathrm{hrs}$ & $4.7 \mathrm{hrs}$ \\
\hline
\end{tabular}

\section{Discussion}

Murchhana of the Ghrita was done for the removal of Ama dosha whichinhibit lipid per oxidation and incorporated antioxidant property for augmentation of medicinal properties of the medicated Taila/Ghrita ${ }^{7,8}$. Ama dosha may be considered as unwanted component among the raw Ghrita, like intermediate chemical constituents, dissolved gases, adulterants, plant toxins and moisture present in raw ghrita or developed due to long time storage. Murchhana helps in maintaining the necessary ratio of unsaturated and saturated fats suitable for human physiology. Kalka dravya was added after adding of Swarasa so that burning of kalka dravya will not takes place and active constituents of drugs will be protected destroyed.

Kalka dravya used for preparation was made in to fine powder so that maximum percentage of active constituents goes in to preparation. The weight of kalka dravya after preparation was increased and found $1690 \mathrm{gm}$. This increase the amount of kalka dravya due to absorption of Ghrita and dravya dravya used in preparation. Weight of Brahmi ghrita was decreased that of Puran Ghrita. From above it is clear that there was loss of Ghrita due to absorption of Ghrita by the kalka dravya. Preparation of Brahmi Ghrita was done on madhyam agni (Medium temperature) at high temperature kalka dravya will get burned because all liquid constituents will be evaporated early and no drava dravya was available for preparation. Due to these ayurvedic doctrines always advices to prepare ghrita preparation over medium temperature in order to incorporate maximum therapeutic properties in Brahmi Ghrita. The Mridu paka is indicates presence of moisture [10] in the Kalka (paste) of herbal drugs and is diagnosed physically by touch and molding into spindle shape (Varti) [11], it seems to be sticky in nature. In the 
Madhyam paka, no moisture [12] remained in Kalka and can be easily molded into spindle shape, but in Khara paka, Esatkathin appeared in the Kalka [13]. Sneha Siddhi Lakshana like "Shabdasya uparame prapte"[14] suggests reduction of water i.e. extent of moisture content. When water remains in the ghrita it produces the cracking sound and this sound disappears gradually after reduction of water. "Gandhavarna rasadinam sampatau" suggest that production of desired specific characteristics of odor, colour, and taste because of active constituents are transferred into the ghrita media. 'Phenashanti'[15] and 'Viphena parichapalagata', specifically for Ghrita suggest that there is no production of any gases resultant into absence of frothing. When kalka dravya of Sneha was put on fire it does not produces any sound that indicate kalka dravya was devoid of moisture. If kalka produces any sound, when it is put on fire that indicates that, kalka is still having some quantity of moisture. When kalka dravya was put between two fingers and roll it, then it attains varti like shape that indicate proper sign of Sneha paka. During this stage the active component of kalka will properly assimilate in the Ghee (Ghrita).

\section{Conclusion}

In present research the formula of Brahmi Ghrita selected from the reference of Charaka Samhita. By following this formula three samples of Brahmi Ghrita were prepared. The quantity of Ghee and others raw materials were taken equally in all three samples (Sample-A, Sample-B, Sample-C) but the final yield of the Brahmi Ghrita was more in Sample-B. The total duration of the Temperature given to the container is more i.e. $10 \mathrm{hrs}$ in Sample-B resulting in to low quantity of kalka with comparing to other two samples. The temperature observed within the kalka during the stage of Siddhi lakshana among all the three samples the Sample-B contains slight enhancement of Temperature i.e. $94{ }^{0}$ C. Since all the observations of three samples (A, B, C) during the manufacturing process of Brahmi ghrita contains without much significant variation. Hence the average values of three samples are to be considered as a Pharmaceutical Standard Parameters of Brahmi Ghrita. This is also supported by further investigation conducted for three samples $(\mathrm{A}, \mathrm{B}, \mathrm{C})$ in experimental models for nootropic activity (Efficacy study), toxicity study and analytical study by showing equally results in all the three samples.

\section{References:}

1. Brahmanand Tripathi Charaka Samhita Hindi commentary Charaka Chandrika Nidan Sthana 7/5 Chaukhambha Surbharati Prakashana, Varanasi.

2. Anantaram Sharma Susurta Samhita with Susrutvimarshni Hindi commentary Uttar tantra 61/3 Surbharti Prakashana,

3. Brahmanand Tripathi Charaka Samhita Hindi commentary Charaka Chandrika Chikitsa Sthana 10/25 Chaukhambha Surbharti Prakashana, Varanasi.

4. Shri Ambiaka data Shastri Vidhotini hindi commentary of Bhaishajya Ratnawali, Jwaradhikara/1285 Chaukhambha Prakashana, Varanasi.

5. Shailaja Srivastava, Sharangadhar Samhita with Jiwanprada Hindi commentary Madhyam Khand 9/1213, Chaukhambha Orientalia Publication Varanasi.

6. Shailaja Srivastava. Sharangadhar Samhita with Jiwanprada Hindi commentary Madhyam Khand 9/7 Chaukhambha Orientalia Publication, Varanasi. 
7. Ambiaka data Shastri Bhaishajya Ratnawali with Vidhyotini hindi commentary Jwaradhikara/1285-1287 Chaukhambha Prakashana, Varanasi

8. Charaka Samhita Commentary by Gangadhara (Jalpakalpataru), Chaukhambha Orientalia, Varanasi.

9. Ambiaka data Shastri Bhaishajya Ratnawali with Vidhyotini hindi commentary Jwaradhikara/1283-1284 Chaukhambha Prakashana, Varanasi

10. Shailaja Srivastava. Sharangadhar Samhita with Jiwanprada Hindi commentary Madhyam Khand 9/14 Chaukhambha Orientalia PublicationVaranasi.

11. Shailaja Srivastava. Sharangadhar Samhita with Jiwanprada Hindi commentary Madhyam Khand 9/12
Chaukhambha

Orientalia

PublicationVaranasi.

12. Shailaja Srivastava. Sharangadhar Samhita with Jiwanprada Hindi commentary Madhyam Khand 9/15 Chaukhambha Orientalia PublicationVaranasi..

13. Shailaja Srivastava. Sharangadhar Samhita with Jiwanprada Hindi commentary Madhyam Khand 9/16 Chaukhambha

Orientalia PublicationVaranasi..

14. Anantaram Sharma Susurta Samhitawith Susrutvimarshni Hindi commentary Chikitsa Sthana 31/12 Surbharti Prakashana, Varanasi. .

15. Anantaram Sharma Susurta Samhitawith Susrutvimarshni Hindi commentary Chikitsa Sthana 31/13 Surbharti Prakashana, Varanasi. 